Int. J. Dev. Biol. 52: 101-107 (2008)

doi: $10.1387 / \mathrm{ijdb} .072342 \mathrm{wk}$

\title{
Polish pioneers in research on vertebrate circulatory systems at the Jagiellonian University of Krakow (Poland)
}

\author{
WINCENTY KILARSKI* \\ Department of Cytology \& Histology, Institute of Zoology, Jagiellonian University, Krakow, Poland
}

\begin{abstract}
At the end of the XIX century and during the first half of the XX century, Henryk Hoyer and Zygmunt Grodzinski, two eminent Polish researchers, were carring out research on the lymphatic circulatory and blood circulatory systems. Later, these investigations were continued by their students and followers until 1966. Embryos from all groups of vertebrates were used for investigation and on that basis, models of the lymphatic and blood circulatory systems were proposed.
\end{abstract}

KEY WORDS: lymph, blood, circulatory systems, yolk platelets

\section{Development of the lymphatic system}

Living animals must be capable of transporting nutrients, wastes and gases to and from cells. Multicellular organisms have developed transport and circulatory systems to deliver oxygen and food to cells and remove carbon dioxide and metabolic wastes. Vertebrates have a closed circulatory system in which the blood is closed at all times within vessels of different size and wall thickness. In this type of system, blood is pumped by a heart through arteries to the organs and is returned by veins but does not normally fill body cavities. The vertebrate closed circulatory system is often referred to as the cardiovascular system.

A secondary circulatory system, the lymphatic circulation, collects fluid and cells from the whole organism and returns them to the cardiovascular system. Water and plasma are forced from the blood capillaries into intercellular spaces. This interstitial fluid transports material between cells. Most of this fluid is collected in the capillaries of the secondary circulatory system, the lymphatic system, at the thoracic duct and right lymphatic duct. Lymph flows from small lymph capillaries into lymph vessels that are similar to veins in having valves that prevent backflow. Lymph vessels connect lymph nodes, lymph organs, and have a connection to the cardiovascular system at the thoracic duct and right lymphatic duct. Lymph nodes are small irregularly shaped masses penetrated by lymph vessels. Clusters of nodes are located in strategic localities of the animal's body and their localization varies in different groups of vertebrates.

In general the model of the lymphatic system of vertebrates that was proposed by Henryk Hoyer $(1934,1938)$ is simple and consists of four pairs of main trunks. Two pairs of trunks run under the axial skeleton (truncilymphaticisubvertebrales) and other two run just under the skin (truncilymphatici laterales and jugulares). The lymphatic hearts characteristic for lower vertebrates are present in various parts of the body and in different number (Fig. $1)$.

Our knowledge about the lymphatic system was clarified at the beginning of the $\mathrm{XX}$ century and the history of its discovery is closely linked with Polish scientists who lived and worked in Krakow University mainly in the Department of Comparative Anatomy. The main problem that stood in front of early investigators was of a technical nature. There were several approaches to visualize the lymphatic vessels. The goal of the anatomical approach - was to visualize the entire lymphatic system in adult animals, mostly mammals. To accomplish this, the investigators tried to fill the lymphatic system via the trunks with a contrast material. They used mercury. The goal of the histological approach was to make series of paraffin sections of parts or the whole bodies of relatively small animals and then make graphical reconstruction. This method was extremely tedious and required endless endurance and ability to interpret the histological image of reconstructed lymphatic vessels. The third approach that was applied by Hoyer (1934) and later by his students, involved the use of a solution of Prussian blue (an aniline stain) or Indian ink to fill the lymphatic vessels. This technique was non-toxic for animal tissue and non-damaging to the delicate lymph vessels. However, all these techniques produced artifacts that generated a great deal of controversy through the centuries.

There were two main intriguing questions on the organization and origin of the lymphatic system. First, is the lymphatic system closed or open? and second, what is the origin of lymphatic

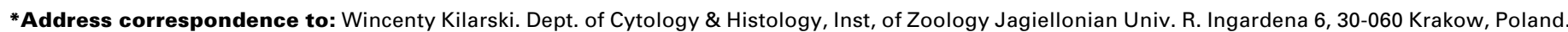
Fax: +48 (12)-634-4951. e-mail: kilar@zuk.iz.uj.edu.pl
}

Published online: 14 February 2008

$0214-6282 / 2008 / \$ 35.00$

(C) UBC Press

Printed in Spain 

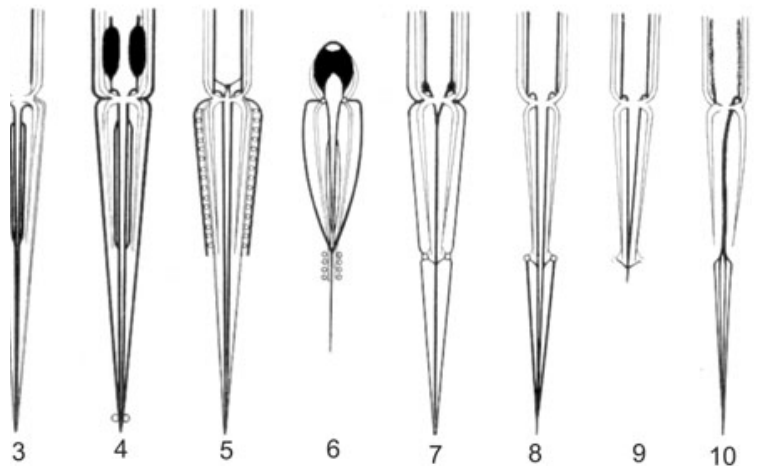

Fig. 1. Diagram of the organization of lymphatic and vein systems in chordate (H. Hoyer, 1934). 1, general schema; 2, lamprey; 3 , dogfish; 4, fish; 5, newt and salamander; 6, frog and toad; 7, lizard; 8, crocodile; 9, bird; 10, mammals. The white empty contours correspond to blood veins. Black contours represent lymphatic veins. Small empty circles represent lymphatic hearts. (H. Hoyer, 1934).

capillaries; do they originate from small tissue fissures or cavities or do they sprout from blood vessels?

The injection techniques applied by Hoyer and developed later by his contemporaries of the Krakow school were most profitable. It required only moderate skills and did not produce significant artifacts. The novel approach applied by Krakow's researchers was to use the embryos instead of adult animals. Embryos are more or less transparent and therefore allow easy visualization and drawing cartoons of the lymphatic system at the beginning of its formation.

These methods allowed Hoyer, to construct a model of the vertebrate lymphatic system. His model was generally accepted by the scientific community and strengthened the view that the lymphatic system of vertebrates is closed and that small lymphatic capillaries have blind ends and originate from the blood veins through budding.

Hoyer, the founder of the Krakow School of Comparative Anatomy, was educated at the universities of Breslau (presently Wroclaw), Berlin and Strasburg. He gained experience in the laboratories of eminent histologists and anatomists, notably $P$. Ehrlich, A. v. Kolliker and G. Schwalbe. From this background, he was suitably prepared to build a prestige scientific school in Krakow after Poland obtained independence in 1918, at the end of World War I.

However, before we present the accomplishment of Hoyer and his collaborators we will present a state of knowledge of the lymphatic system of vertebrates that existed in XIX century Europe. The general opinion that prevailed during the XIX century was that the lymphatic vessels originate from the tissue cavities or fissures and that the whole system is open. Such renowned scientists like R. Virchov and M. Donders (1854) who based their vision mostly on histological observations propagated these ideas. Their ideas were strongly supported by distinguished physiologists M. Brucke (1854) and C. F. W. Ludwig and the histologist F. v. Recklinghausen (1871).

In the second half of the XIX century, L. Teichman, Professor of Anatomy in Krakow University, observed and described the "closed lymphatic canals" that grow during animal development. Therefore we may consider him a pioneer of Polish school of anatomy of the lymphatic system. Also, he had described the endothelial cells that lined the lymphatic vessels and named them the lympho-vascular cells (1861). There was, however, a great controversy about the existence of these cells. They were first noticed by Recklinghausen (1862), and, in the same year, by Hoyer Sen., Professor of Anatomy in Warszawa. However, despite his important discovery, Reclinghausen did not abandon his previous but erroneous opinion about the open nature of the lymphatic system.

At the end of the XIX century, the works of C. Rouget (1873) and Kolliker (1885) on the lymphatic vessels of frog tadpole's tails directed the attention toward the origin of the lymphatic vessels during animal development, with the strong suggestion that the whole system is a closed entity. The traces of these ideas were also found in the works of L. A. Ranvier (1895) and supported in the early years of the XX century by A. B. MacCallum (1902), who independently from Hoyer Jr., used Prussian blue stain for injection of lymphatic vessels and undeniably overthrew the idea of Recklinghausen. This technique was successfully used by $\mathrm{L}$. Mierzejewski (1909) and F. R. Sabin (1909) and later also by J. Zacwilichowski (1917) who investigated the origin of the pectoral lymphatic sack (cysterna chili or' saccus lymphaticus) that ends the pectoral lymphatic trunk (ductus thoracicus) and also lym-

\section{A}

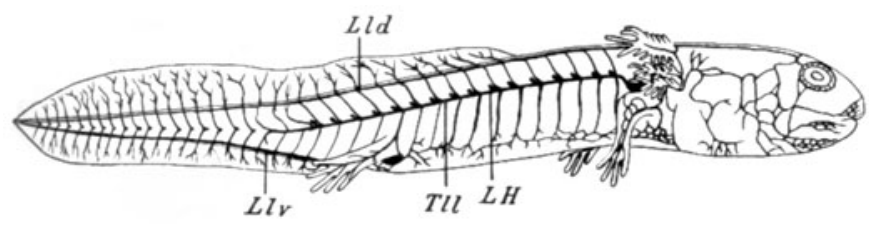

B

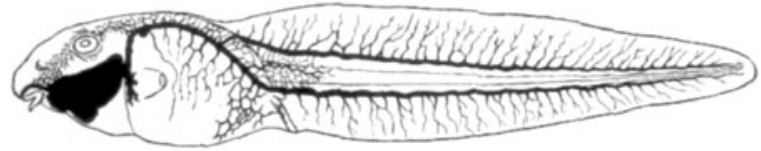

Fig. 20. von der lateralen Seite.

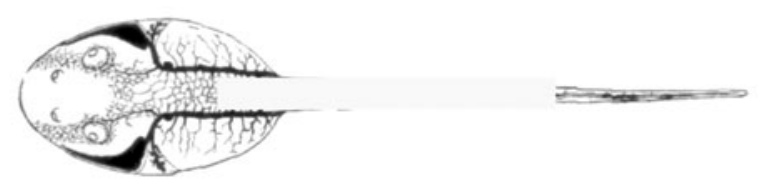

Fig. 21. von der dorsalen Seite.

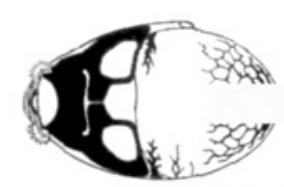

Fig. 22. von der ventralen Seite.

Fig. 2. Organisation of the subcutaneous lymphatic systems in Amphibian tadpoles. (A) Salamandra maculosa, side view. Lld, truncus lymphaticus longitudinalis dorsalis; LIV, truncus lymphaticus longitudinalis ventralis; TIl, truncus lymphaticus longitudinalis lateralis; LH, cor lymphaticus. (B) Rana temporaria, side view, dorsal view and ventral view respectively. (A) H. Hoyer and S. Udziela, 1912; (B) H. Hoyer, 1905. 
phatic heart in birds, cows, human embryos and mole. They also documented that the pectoral sack originates from small blood vessels.

As mentioned at the beginning of this article, Hoyer's biggest achievement was the idea to apply the injection technique to small almost transparent embryos of lower vertebrates and to trace the origin of the lymphatic system ontogenetically and phylogenetically. In 1905 he started to search for the origin of the lymphatic system in frog tadpoles and later in salamander tadpoles (1911) (Fig. 2), and discovered that the pectoral lymphatic sack present in higher vertebrates is homologous to the pectoral lymphatic bud in the frog tadpole. He found that it originated from a branch of the intersegmental vein (vena intersegmentalis) of the blood circulatory system. The outgrowth expands and forms a sack whose walls consisted of striated muscle and, finally, becomes the front lymphatic heart.

In $1911 \mathrm{~J}$. Baranski investigated and illustrated the origin of the lymphatic vesicle in the trunk of the tail of the frog tadpole, which buds off from the wall of inter segmental veins ( $v v$. intersegmentales) and differentiates into the rear lymphatic heart. According to Baranski, this vesicle is equivalent of the neck lymphatic sack of higher vertebrates. In amphibians, the rear hearts remain through the life of animal. These collect the lymph from the rear part of the body and pump it to the blood veins. Similar hearts have also been described in reptiles and in some birds (anseriformes, ciconiformes, ratitae) but in most birds the lymphatic hearts disappear during embryogenesis. Amphibian tadpoles were quite extensively and successfully explored owing to transparency of their bodies and easy maintenance in the laboratory. In 1911 A. Diurzynski investigated the development of the lymphatic system during the regeneration of the tadpole's extremities and tails. His findings supported the opinions of the previous authors that the lymphatic vessels grow circumferentially after the establishment of the blood vessels.

Besides amphibian larvae, the second type of larvae suitable for exploration of the lymphatic system was a fish larva. They are also transparent, usually easy obtainable, and could be kept alive in the laboratory for several weeks. The first reports on the fish lymphatic system date to the first half of the XIX century. The works of V. Fohmann (1827) and R. Lippi (1825) are limited to the information that the lymphatic trunks interconnect with the blood vessels in several places. This obviously erroneous statement arose from artifacts created by the injection of the system with mercury, which destroyed the delicate lymphatic vessels in several places and floated to blood vessels. It is worthwhile; however, to mention an improbable point of view of several distinguished investigators like L. Agassiz (1856) and C. Vogt (1856) who stated that lymphatic vessels are joined through so called "mucous canaliculi" with the blood vessels and finally communicate with the surrounding water. At the end of XIX century P. Mayer (1888) doubted that the lymphatic system existed at all in fish. He had misinterpreted the presence of lateral line canals with that of lymphatic trunks.

On the basis of experience with amphibian tadpoles, Hoyer and WI. Michalski (1911) decided to follow the origin of the lymphatic system in trout larvae (Salmo trutta), which were easily obtained in Krakow from the nearby fish aquaculture. The main problem they met during that study was to recognise and to distinguish the blood vessels from the lymphatic vessels. Their observations led them to describe two general types of lymphatic trunks, peripheral trunks (trunci lymphatici superficiales) and those located inside of the body under the vertebra (trunci lymphatici subvertebrales). They also described the primordial lymphatic trunks that form in early fish larvae before hatching and secondary lymphatic system established after hatching and yolk digestion (Fig. 3).

In 1928, Hoyer started to investigate the lymphatic system of sharks, the existence of which had not been demonstrated satisfactorily because it was difficult to distinguish the blood veins from the lymphatic veins. T. J. Parker (1886) and later F. Hochstetter (1906) based their interpretation on the comparison of the lymphatic system described in fish with what they described in sharks. Their conclusion was wrong and they left many questions unanswered. For that reason, Hoyer decided to study that problem "ab ovo" and distinguish both systems in the same specimen using double injection. He injected the lymphatic system of different stage shark embryos (Scylium canicula) with Prussian blue and the blood circulatory system with Indian ink. The results he obtained were widely accepted and published in a very
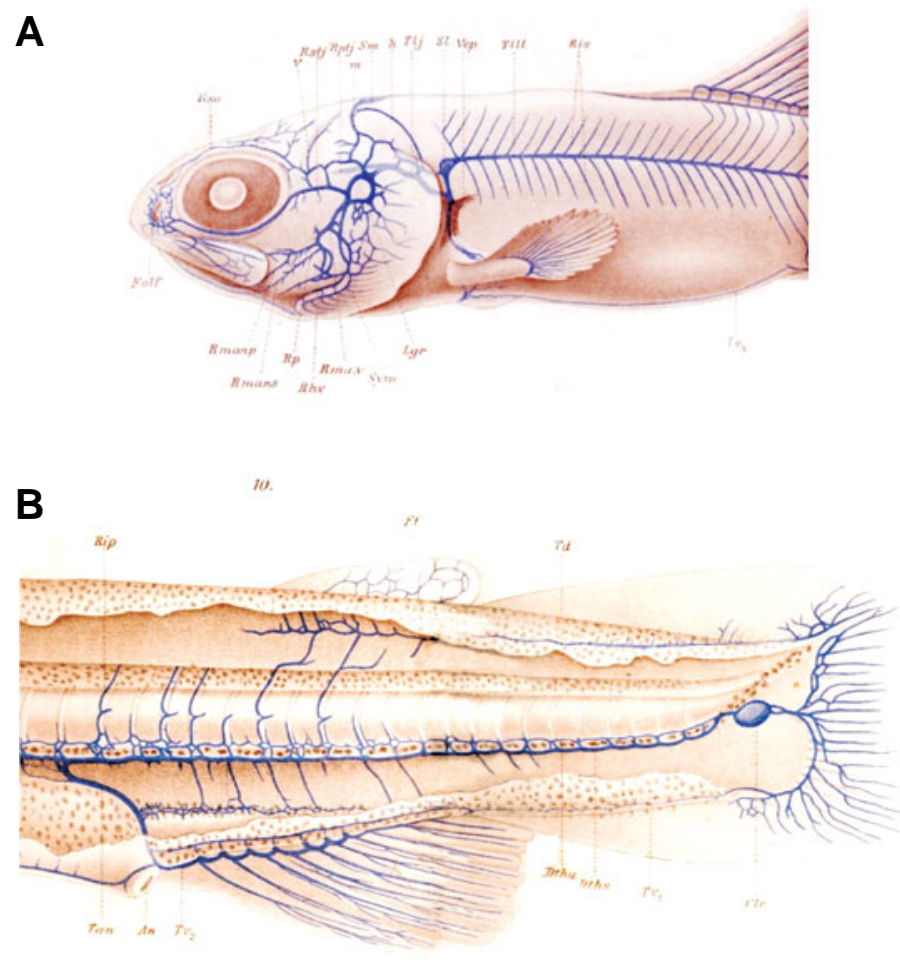

Fig. 3. Distribution of the surface lymphatic veins on the head $(A)$ and trunk (B) of trout (Salmo trutta). Rso, ramus supraorbitalis; V, vena; Rstj, ramus superficialis trunci jugularis; Rptj, ramus profundus trunci jugularis; Sm, sinus medullaris; $h$, lymphatic heart; Tlj, truncus limphaticus jugularis; Vep, vena cardinalis posterior; TIII, truncus lymphaticus longitudinalis lateralis; Ris, ramus intersegmentalis superficialis; Folf, fovea olphactoria; Rmanp, ramus mandibularis profundus; Rmans, ramus lymphaticus maxillaris superficialis; $R p$, ramus pseudobranchialis; $R$ hv, ramus hyoideus ventralis; Rmax, ramus maxillaris; Sym, symplecticum; Lgr, lymphatic large circle; Tv4, truncus lymphaticus ventralis. (H. Hoyer and W.I. Michalski, 1912). 
prestigious journal in 1928. He definitively distinguished the lymphatic system from the blood circulatory system and established that the lymphatic pectoral trunk (ductus thoracicus) originates very early during embryonic development (stage $Q$ according to Balfour, 1876) when the shark larva reaches $30 \mathrm{~mm}$ in length. One of Hoyer's students, Z. Grodzinski, continued the work of his master. Following Hoyer's suggestion, Grodzinski continued study on the formation of the ductus thoracicusin swine embryos and showed that it originated on the wall of the aorta as a net of small capillaries. These, during further growth of the embryos, joined into two lymphatic trunks. These trunks run parallel to each other but later in development, one of them vanishes (1922). In 1924, Grodzinski used old injected specimens of the lamprey larva (Petromyzon planer) that were injected by $B$. Mozejko in 1910, to histological study the development of the lymphatic canal. Z. Grodzinski left for a certain period of time the problem of the lymphatic system and initiated a new project on the formation and organisation of the blood circulatory system in vertebrates.

\section{Development of the blood circulatory system}

Since Aristotle, such prominent embryologists as M. Malpighi, W. Harvey, C. F. Wolf, H. Rathke and C. E. v. Baer-were involved in the study of chicken embryos. In their observations, which were focused on the development of various parts of the chicken body, they also paid attention to the distribution and dynamic development of the blood circulatory system. This was a relatively easy task since the chicken embryo is transparent and blood vessels filled with blood are readily visible. However, the most intensive studies of the circulatory system, exploded at the beginning of the $X I X$ century and lasted throughout the first half of the $X X$ century. In Poland, Krakow was the major centre of research on the blood circulation. Zygmunt Grodzinski, successor of Hoyer in the Department of Comparative Anatomy, founded the Krakow school of blood circulation and propagated successfully this direction of study until 1966.
In 1900,W. His introduced the idea of angioblast as the tissue from which a material for future blood vessels originated. His's hypothesis was finally confirmed 27 years later by the Polish scientist P. Slonimski (1927) who demonstrated that material for blood vessels and blood corpuscles originates from the tissue located just under the notochord. He excised small tissue fragments from Ambystoma embryos (Ambystoma mexicanum) and cultivated them in Petri dishes obtaining tissue culture of red blood cells and endothelial cells. Meanwhile, in the Department of Comparative Anatomy in Krakow the pupils of Hoyer started a series of studies on the development of the blood circulatory system in vertebrates. Grodzinski had focused on the origin of vessels in the yolk sack of Amphibians $(1924,1925)$ and the main blood vessel in fish (1925). He also published the splendidly illustrated paper on the analysis of blood vessel development in the snake (Tropidonotus natrix) (1928). It is striking that Grodzinski did not work according to a specific plan but jumped from one animal group to another without an established taxonomic sequence. In 1927, he published a paper on the development of the vascular formation in the limbs of the axolotl, and in 1928 on the circulatory system in sharks (Scylium canicula). Although it is difficult, to follow and construe the behaviour of a researcher retrospectively from such a long distance in time it seems that the lack of taxonomic sequentiality in Grodzinski's studies originated either, from the periodic unavailability of the appropriate material or, from the wish to break the monotony of the study of similar subjects. After a short break, however, Grodzinski returned to investigate reptile and fish extremities. He presented results that centred on the development of the circulatory system in the limbs of turtle (Emys orbicularis) (Fig. 4) and in the fins of salmon (1930, 1931). At the end of the series of studies on the main blood vessels in the limbs of lower vertebrates, Grodzinski published a monographic paper that summarised that scientific endeavour (1933). Grodzinski influenced other investigators in the same department: J. Wilburg described development of blood vessels in the swine foot (1931), and J. Marchlewski the development of blood vessels in the nasal cavity (1933). In 1934, Grodzinski
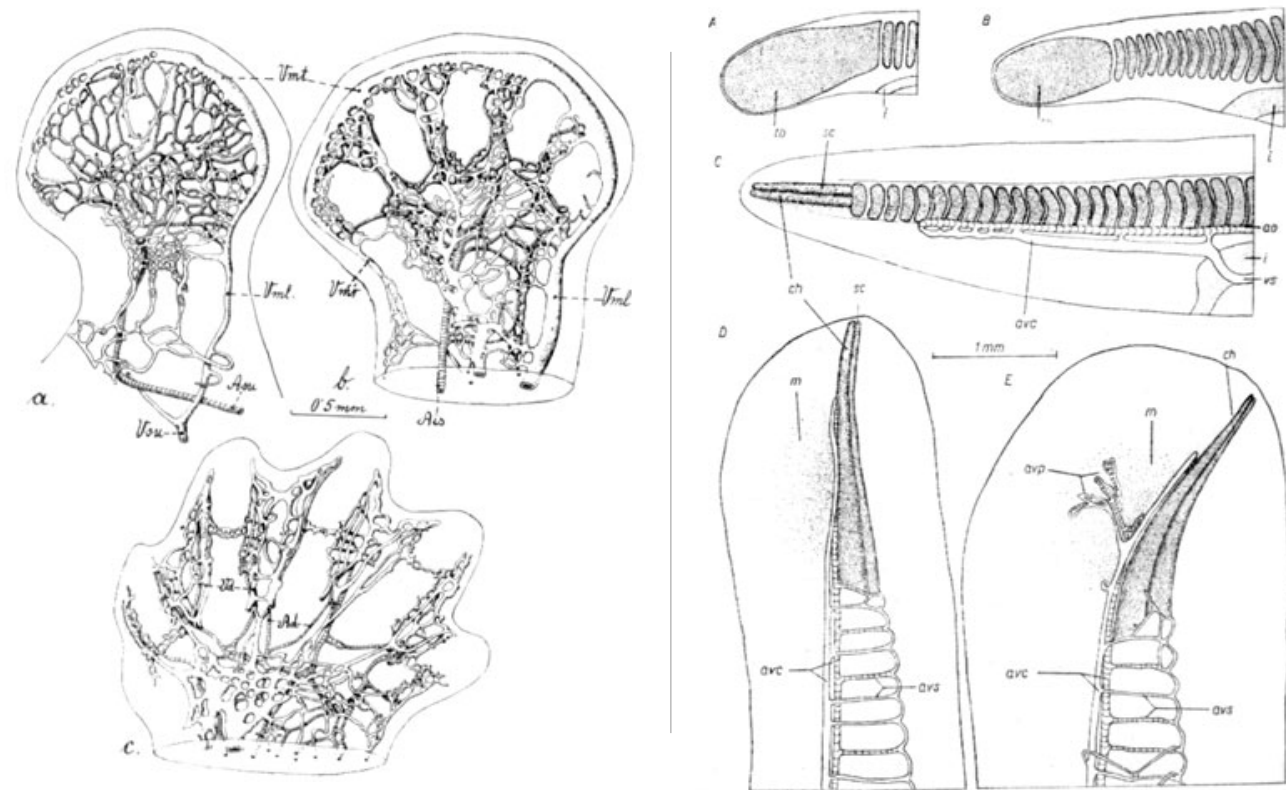

Fig. 4 (Left). Development of the blood circulatory system in extremities of turtle (Emys orbicularis). Vmt, vena marginalis; $V m l$, vena marginalis lateralis; Vmr, vena marginalis recessiva; Vsu, vena ulnaris; Asu, arteria ulnaris; Ais, arteria interossea; Vol, vena digitalis; $A d$, arteria digitalis. ( $Z$. Grodzinski, 1930).

Fig. 5 (Right). Development of the tail of trout (Salmo trutta) and formation of the primordial circulatory system. Avc, caudal arteries and veins; avs, intersegmental veins and arteries; avp, arteries and veins of caudal pin; tb, tail bud; i, intestinum; sc, somites primordial tissue; ch, chorda dorsalis; ao, aorta; vs, vena subintestinalis; Sc, caudal somites; $m$, tissue material for caudal pin. (Z. Grodzinski, 1959). 
returned from the USA where he had spent his sabbatical and started to study vascular formation on the yolk sack of chicken and also he and his student (W. Swiety) continued the study of the vascular system in the wing of birds (1934, $1935,1937)$. The comparative study on the vascular system of vertebrate extremities during development gave an impulse to propose the model of the formation of circulatory system in vertebrates that Grodzinski published, unfortunately only in Polish, at the end of his scientific career in 1962.

The early study of chicken embryos inspired Grodzinski to investigate the composition and physical properties of the yolk mass of the hen egg $(1938,1946)$. Studies of the structure of yolk mass continued until1965 and were extended on the study of the yolk of hagfish, bony fishes and Holostean fishes. These studies were carried out together with his student who introduced to these investigations, methods of electron microscopy $(1969,1971,1982)$.

After the 1939 - during World War II - Polish scientists were forced to abandon science. They were prisoners in concentration camps or they had to work as labourers to survive and support their families. Immediately after the end of the war, the situation in research started to normalise but in very limited scope.

After the Word War II, Grodzinski was involved in organization of science and teaching; therefore auxiliary studies on the formation of blood vessel were continued under his guidance, by his students. He himself started a new subject concentrating on the susceptibility of the developing heart of fish embryos to different physical stresses $(1949,1950)$. During this period, several investigators affiliated with the Department of Comparative Anatomy started a new project on development of the vascular system in the gills of fish embryos. The main goal of this project was to investigate formation of an auxiliary respiratory surface in fish embryos whose gill arches are not yet well developed. The paper by W. Solewski $(1949,1951)$ started a whole series of papers on this subject that later branched into other supplementary respiratory organs in fish such as yolk sack and skin. In $1949 \mathrm{~S}$. Strawinski used old injected specimens from a batch stored in the Department and studied the blood vessels of trout embryos.

Five years later, Grodzinski returned to his earlier studies on the development of fish embryos and described the relationship between somite formation and the newly formed blood vessels in the tail (Fig. 5) and the formation of lymph heart (1955, 1959, 1959a). In the same year, 1955, J. Ziemba investigated the formation of blood vessels in the yolk sack of pike (Esox lucius) and suggested that these vessels play an important role in forming an additional respiratory organ in fish embryos (1956). A. Olko focused her attention on a similar subject but in trout embryos (1955) and obtained similar results. Independently, F. Markiewicz (1960) described blood vessel formation in the gills of pike embryos (Esoxs lucius) while W. Byczkowska (1961) investigated and calculated the respiratory surface in the gills of rainbow trout (Salmo gairdneri Gibb.) during development. The study of the respiratory surface in fish embryos continued until 1965. A. Jasinski studied easily obtainable ovoviviparous fish "guppy" (Poecilia reticulata Peters) and described a rich net of respiratory blood vessels in the embryo yolk sac (1965). One year later his student, L. Goniakowska (1966), described the development of the blood vessels in the tail of fish embryos previously injected by Jasinski. The papers of Goniakowska and Jasinski concluded the long-lasting project of investigation of formation of the lymphatic and blood circulatory systems in vertebrates.

Last picture illustrate the icons of two founders of Polish centre of research on the lymphatic and blood circulation systems, $\mathrm{H}$. Hoyer (A) and Z. Grodzinski (B) respectively (Fig. 6).

\section{Acknowledgements}

The author thanks Professor N. J. Severs for helpful comments on the manuscript and Professor L. Witalinska for allowing me to use the library in her Department of Comparative Anatomy.

\section{References}

AGASSIZ, L. (1856). Uber das wassergefäss system der Molusken Zeitschr. wiss. ZOOl. 7.

BALFOUR, F. M. (1876). On the Development of Elasmobranch Fishes. J. Anat. And Physiol. Vol. 10, 377-413

BARANSKI, J. (1911). Die Entwicklung der hinteren lymphherzen bei der Unke (Bombinator) Bulletin de l'Acad. Cracovie Sér. B, 3, 170-178

BYCZKOWSKA, W. (1961). Rozwoj powierzchni oddechowej w skrzelach pstraga teczowego (Salmo irideus Gibb.). - Development of the respiratory surface in the gills of the rainbow - trout (Salmo irideus Gibb.). Acta. Biol. Crac. Sér. Zool. 4, 89-109

DZIURZYNSKI, A. (1911). Untersuchungen uber die Regeneration der blut- und Lymphgefäss im Schawanze von Froschlarven. Bulletin de l'Acad. Cracovie Sér. B, 4, 187-224

FOHMANN, V. (1827). Das Saugadersystem der Wirbeltiere. Heidelberg u. Leipzig

GONIAKOWSKA, L. (1966). Rozwoj naczyn krwionosnych w ogonie guppi (Lebistes reticulataPeters).- The development of the blood vessels in the tail of the guppy (Lebistes reticulata Peters). Acta Biol. Crac. Sér. Zool. Vol IX, 187-197

GRODZINSKI, Z. (1922). Przyczynek do rozwoju przewodu piersiowego (ductus thoracicus) u zarodkow Swin. - Zur Entwicklung des Ductus thoracicus bei Schweinembrionen. Bulletin de l'Acad. Polonaise des Sciences, Série B. 183184

GRODZINSKI, Z. (1924). Rozwoj kanalu endolimfatycznego u minoga Petromyzon planeriBl. - Uber die Enwicklung des Ductus endolymphaticus von Petromyzon planeriBI. Bulletin de l'Acad. Polonaise des Sciences, Série B. 515-520 
GRODZINSKI, Z. (1924). Rozwoj zyl jelitowo-zoltkowych u plazow ogoniastych. Uber die Entwicklung der Gefäss des Dottedarmes bei Urodelen. Bulletin de l'Acad. Polonaise des Sciences, Série B. 57-67-520

GRODZINSKI, Z. (1925). Dalsze badania nad rozwojem naczyn krwionosnych u lososiowatych. - Beitrage zur Enwicklung der Blutgefäss der Salmonidenembrynen. Bulletin de l'Acad. Polonaise des Sciences, Série B. 623-631

GRODZINSKI, Z. (1927). Rozwoj naczyn krwionosnych w odnozu przednim u Amblystoma mexicanum Cope. - Die Blutgefässnwicklung in der vorderen Extremitat bei Amblystoma mexicanum. Bulletin de l'Acad. Polonaise des Sciences, Série B. 247-266

GRODZINSKI, Z. (1928). Rozwoj naczyn krwionosnych u Scylium canicula L. Entwicklung der Blutgefäss bei Scylium caniculaL. Bulletin del'Acad. Polonaise des Sciences, Série B. 417-454

GRODZINSKI, Z. (1928). Rozwoj naczyn krwionosnych u zaskronca. - Die Blutgefässntwicklung bei der Natter, Tropidonotus natrix. Bulletin de l'Acad. Polonaise des Sciences, Série B. 1-110

GRODZINSKI, Z. (1930). Rozwoj naczyn krwionosnych w odnozu przednim zolwia Emys orbicularis. - Die Blutgefässntwicklung bei Emys orbicularis. Bulletin de l'Acad. Polonaise des Sciences, Série B. 583-587

GRODZINSKI, Z. (1931). Rozwoj naczyn krwionosnych w pletwie u ryb z rodzaju Salmo. - Die Blutgefässntwicklung in der Brustflosse der Gattung Salmo. Bulletin de l'Acad. Polonaise des Sciences, Série B. 567-582

GRODZINSKI, Z. (1933). Rozwoj i anatomia porownawcza osiowych naczyn krwionosnych w przednich konczynach u kregowcow. Cz. I ill. - Vergleichende Entwicklungeschichte and Anatomie der axialen Blutgefäss in der vorderen Extremitaten der Wirbeltiere. Bulletin de l'Acad. Polonaise des Sciences, Série B. 243-338

GRODZINSKI, Z. (1934). Z badan nad rozrostem Area vasculosau kurczecia. - Zur Kenntnis der Wachstumvorgange der Area vasculosabei Huhnchen. Bulletin de l'Acad. Polonaise des Sciences Série B. 415-426

GRODZINSKI, Z. (1935). Rozwoj zyl w tarczy zarodkowej kurczecia. - Die Entwicklung der Vene In der Keimscheit des Huhnchens. Bulletin de l'Acad Polonaise des Sciences. Série B. 305-322

GRODZINSKI, Z. (1938). Cytologiczne badania zoltka jaja kurzego w zwyczajnych i doswiadczalnych warunkach. - Zur Morphologie des Huhnereidotters unter normalen und experimentallen Bedingunge. Bulletin de l'Acad Polonaise des Sciences. Série B. 317-355

GRODZINSKI, Z. (1946). Wplyw wzrastajacego cisnienia osmotycznego na kule zoltka bialego $\mathrm{z}$ jaja kury. - Influence on the increase in the osmotic pressure upon the white yolk spheres of the hen's egg. Bulletin de l'Acad Polonaise des Sciences. Série B. 59-137

GRODZINSKI, Z. (1949). Wplyw przemiennych temperatur na tetno serca zarodkow troci Salmo trutta L. - The influescence of The alternating temperatures upon the heart rate of the embryos of the Sea-trout Salmo trutta L. Bulletin de l'Acad Polonaise. Série B. 195-214

GRODZINSKI, Z. (1950). Wrazliwos serca zarodkow troci Salmo trutta L. na male zmiany temperatury.- Susceptibility of the heart of the Sea trout Salmo truttaL. to small changes in temperature. Bulletin de l'Acad Polonaise. des Sciences Série B. 173-182

GRODZINSKI, Z. (1955). The development of the tail in the Sea-trout Salmo trutta L. Bulletin de l'Acad Polonaise C. II- Vol. III No 3. 103-108

GRODZINSKI, Z. (1959). Rozwoj naczyn krwionosnych w pletwie ogonowej troci Salmo truttaL. - The development of the blood vessels in the tail of the Se-trout Salmo trutta L. Acta. Biol. Crac. Sér. Zool. 11, 185-207

GRODZINSKI, Z. (1959). The development of the lymph heart in the Sea-trout Salmo trutta L. Bulletin de l'Acad Polonaise des Sciences. CI. II Vol. VII, No 8, 305-311.

GRODZINSKI, Z. (1962). Zasady rozwoju naczyn krwionosnych u kregowcow. Principles of blood Vessels Development in Vertebrates. Studia Societatis Scientarum Torunensis. Vol. VI. Nr 1. 1-44

GRODZINSKI, Z., KILARSKI, W. (1971). The yolk of the atlantic hagfish Myxine glutinosa L. Folia Histochem. Cytochem., 9, 1, 3-12

HIS, W. (1900). Lecitoblast und angioblast der Wirbeltiere. Abhan. Mat. Phys. Cl. Sächs Gest. Wissenschaft. 26

HOHSTETTER, F. (1906). Die Entwicklung des Blutgefäss sytems. Hertwig's
Handb. Vergl. u. expt. Entwickl., Bd. 3, Tiel 2, 21-115

HOYER H, und MICHALSKI, WL. (1915). Das Lymphgefäss sytem bei Forellenembryonen (Salmo fario) Bulletin de l'Acad. Cracovie Sér. B 213-216

HOYER, H. (1905). Untersuchungen über Das Lymphgefäss system Der Froschlarven Bulletin de l'Acad. Cracovie Sér. B 417-430

HOYER, H. (1928). Recherches sur les vaisseaux lymphatiques des Sélaciens Bulletin de l'Acad. Cracovie Sér. B

HOYER, H. (1934) Das Lymphgefäss system Der Virbeltiere vom Stadpunkte der Vergleichenden Anatomie. Mem. Ac. Pol. Cl. Méd. 1-204

HOYER, H. und UDZIELA, S. 1911. Untersuchungen uber das Lymphgefäss system von Salamanderlarve, Morph. Jahrbuch. XLIV, 3, 535-557

JASINSKI, A. (1965). Rozwoj naczyn oddechowych u zarodkow jajozyworodne guppi (Poecilia reticulata Peters). - Development of the respiratory vessels in the embryos of the ovoviviparous guppy (Poecilia reticulata Peters). Acta Biol. Crac. Sér. Zool. Vol VIII, 31-40

KILARSKI, W., GRODZINSKI, Z. (1969). The yolk of Holostean fishes. J. Embryol. exp. Morph., 21, 2, 243-254.

LANGE, R. H., GRODZINSKI, Z., KILARSKI, W. (1982). Yolk-platalet crystals in three ancient bony fishes: Polypterus bichir (Polypteri), Amia calva L., and Lepisosteus osseus (L.) (Holostei). Cell Tiss. Res. 222,, 159-165.

LIPPI, R. (1825). Illustrazioni fisiologische e pathologische dei Systema limfaticochilifere mediante la scoperta di un gran numere di communicazioni di esso con venoso. Firenze

MAC CALLUM, W. G. (1902). Die Beziehung der Lymphgefäss zum Bindgewebe. Arch. Anat. u. Phys. Anat. Abt.

MARCHLEWSKI, J. (1933). Rozwoj naczyn krwionosnych jamy nosowej Swini domowej. - über die Entwicklung der Blutgefäss in der Nasenhohle bei Hausschwein. Bulletin de l'Acad. Polonaise des Sciences, Série B. 125-140

MARKIEWICZ, F. (1960). Rozwoj naczyn krwionosnych w lukach skrzelowych szczupaka (Esox lucius L.) - Development of blood vessels in the branchial arches of the pike (Esox lucius L.). Acta. Biol. Crac. Sér. Zool. Vol. 3, 163-170

MAYER, P. (1888). Uber Eingetumlichkeiten in des Kreislaufsorganen der Selachier. Mitteil. Zool. Station Neape/B. 8

MIERZEJEWSKI, L. (1919). Beitrag zur Enwicklung des Lymphgefäss system der vogel. Bulletin de l'Acad. Cracovie Sér. B, 7, 472-482

MOZEJKO, B. (1910). Étude sur le systéme circulatoire de la Lamproie (Petromyzon fluviatilis). Anat. Anz. 36.

OLKO, A. (1955). The respiratory vessels of the yolk sac of the trout Salmo trutta L. Zool. Poloniae 6, 3, 216-225

PARKER, T. J. (1886). On the Blood Vessels of Mustellus antarcticus: a Contribution to the Morphology of the Vascular System in the Vertebrates. Phil. Trans. Roy. Soc. Londyn Vol. 177 B, Pt. 2, 685-732

RANVIER, L. (1895). Development des vaisseaux lymphatiques. C. R. Paris, T. 121

ROUGET, C. (1873). Mémoire sur le développement, la structure, les proprietés physiologiques des capillaries sanguins et lymphatiques. Arch. Physiol. Norm. Pathol. 5, 603-

SABIN, F. R. (1909). The lymphatic system in human embryos. Amer. Journ. Anat. V. $9,43-$

SLONIMSKI, P. (1927). Uber die Darstellung winziger Blutgefäss mittelst der Benzidinprobe. Zeitsch. f. wiss. Mikr. u. mikr. Tech. B. 44

SOLEWSKI, W. (1949). Rozwoj naczyn krwionosnych skrzel u troci Salmo truttaL. - The development of the blood vessels of the girls in the sea-trout, Salmo trutta L. Bulletin de l'Acad Polonaise des Sciences. Série B. 121-144

SOLEWSKI, W. (1951). Rozwoj naczyn krwionosnych u rozanki Rhodeus sericeus Pall. - The development of the blood vessels in the Bitterling Rhodeus sericeus Pall. Bulletin de l'Acad Polonaise des Sciences. Série B. 145-164

STRAWINSKI, S. (1949). Rozwoj naczyn watrobowych u troci Salmo truttaL. - The development of the blood vessels of the Sea-trout Salmo trutta L. Bulletin de l'Acad Polonaise des Sciences. Série B. 435-446

SWIETY, W. (1937). Starsze stadia rozwojowe tetnic i zyl w skrzydle kurczat. - Über altere Entwicklungsstudien der Arterien und Venen im Flugel des Huhns. Bulletin de l'Acad Polonaise des Sciences. Série B. 59-137

TEICHMANN, L. (1861). Das Saugadersystem vom anatomisches Stapunkte berarbeitung. Leipzig 124, 16-. 
VOGT, C. (1856). Uber die Schleimkänale der Fische. Zeitsch. f. wiss. Zool. 7

von KOLLIKER, A. (1885). Histologische Studien an Betrachierlarven. Zeitschr. f. wiss. Zool. B. 43

von RECKLINGHAUSEN, F. (1871). Das Lymphgefäss system. Strickers Handbuch der Lehre von den Geweben. B.1, Leipzig

von RECLINGHAUSEN, F. (1862). Die Lyphmgefäss und ihre beziehung zum Bindgewebe. Berlin.
WILBURG, J. (1931). Rozwoj naczyn krwionosnych w stopie i palcach u Sus scrofa domestica. - Die Entwicklung der Blutgefäss im Mittefusse und in den Zehen bei Sus strofa domestica. Bulletin de l'Acad. Polonaise des Sciences, Série B. 273305

ZACWILICHOWSKI, J. (1917). Die Entwicklung der lymphherzen beim Molch (Molge vulgaris). Bull. Ac. Sc. Cracovie, Sér. B, 4- 6, 134-144

ZIEBA, J. (1956). Naczynia woreczka zoltkowego szczupaka (Esox lucius). Biuletyn Biologii Stawow PAN3. 2-18

\section{Related, previously published Int. J. Dev. Biol. articles}

See our recent Special Issue Developmental Biology in Poland edited by Kloc, Maleszewski and Tarkowski at: http://www.ijdb.ehu.es/web/contents.php?vol=52\&issue=2-3

See our Special Issue Mammalian Reproduction \& Development in honor of Anne McLaren and edited by Brigid Hogan at:

http://www.ijdb.ehu.es/web/contents.php?vol=45\&issue=3

Vascular development: from precursor cells to branched arterial and venous networks

Anne Eichmann, Li Yuan, Delphine Moyon, Ferdinand leNoble, Luc Pardanaud and Christiane Bréant

Int. J. Dev. Biol. (2005) 49: 259-267

Vasculogenesis and angiogenesis in the mouse embryo studied using quail/mouse chimeras

Michel Pudliszewski and Luc Pardanaud

Int. J. Dev. Biol. (2005) 49: 355-361

Conversion of red blood cells (RBCs) from the larval to the adult type during metamorphosis in Xenopus: specific removal of mature larvaltype RBCs by apoptosis.

Y Tamori and M Wakahara

Int. J. Dev. Biol. (2000) 44: 373-380

Co-culture of contiguous developmental fields in a serumless, chemically-defined medium: an in vitro model permissive for coordinate development of the mouse ear.

D S Hoffman, P Bringas and H C Slavkin

Int. J. Dev. Biol. (1996) 40: 953-964

Immunoregulatory factors contributing to fetal allograft survival.

D Rukavina, M Kapovic and A Radojcic

Int. J. Dev. Biol. (1991) 35: 275-278

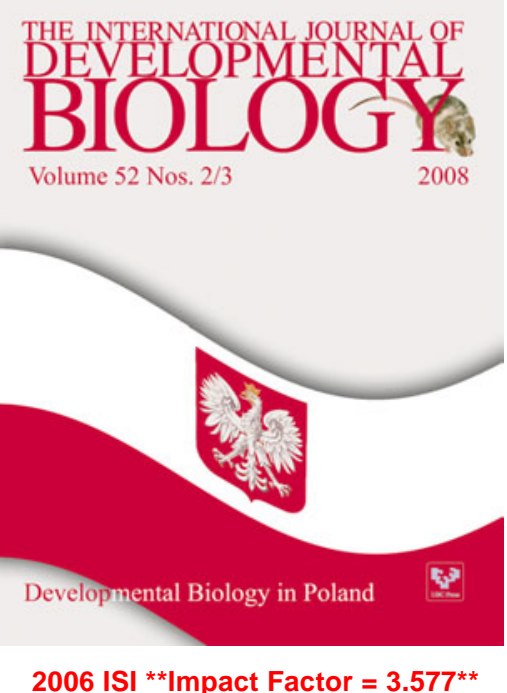

2006 ISI **Impact Factor $=3.577^{*}$

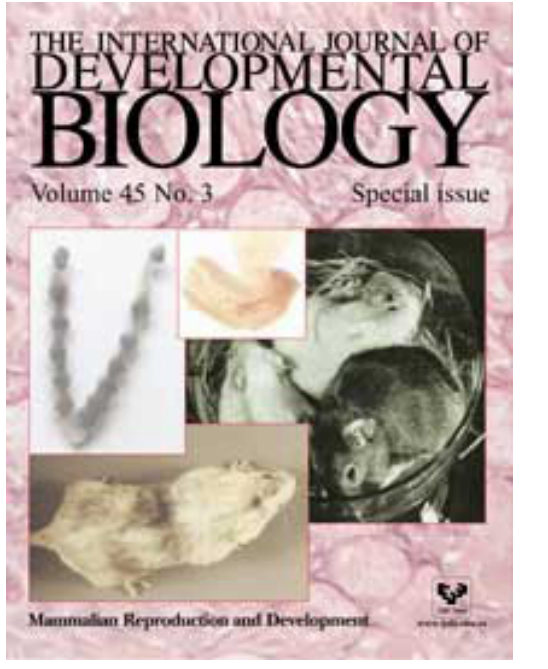

